\title{
ISOLASI DAN AKTIVITAS ANTIMIKROBA AKTINOMYCETES DARI TANAH KARST TAMAN WISATA BANTIMURUNG ASAL MAROS SULAWESI SELATAN
}

\author{
Fhahri Mubarak ${ }^{1}$, Herlina Rante ${ }^{2}$, Natsir Djide ${ }^{2}$ \\ ${ }^{1}$ Sekolah Tinggi IImu Farmasi Makassar \\ ${ }^{2}$ Fakultas Farmasi Universitas Hasanuddin Makassar \\ Email : fhahrimubarak@gmail.com
}

\begin{abstract}
The increasing number of deaths caused by infection encourage researchers conduct early stage in the search for new antibiotics to resolve the issue. This study aims to isolate microbes aktinomicetes contained in karst areas of Bantimurungtourist park district South Sulawesi province to see the antimicrobial inhibitory activity. The initial stage to get new antibiotics, researcher isolated, identified, characterized and tested the antimicrobial activity of isolates to be studied. One of microbes widely studied to be taken of its active compound is aktinomycetes. The research phase is actinomycetes isolation, isolates purification, and testing isolates antagonistic actinomycetes to see whether there is a power resistor formed. From the results obtained 8 isolates actinomycetes isolation, but only 6 isolates that can be grown back properly. Six of isolates actinomycetes obtained, tested antagonist was done to see the activity of inhibitory power. Two of active isolateswas obtained that have inhibitory against several microbes that $\underline{P}$. aeruginosa and $\underline{S}$. aureus which is then coded isolates of K21 and K32.
\end{abstract}

Keywords: Isolation, actinomycetes, antimicrobial activity, Karst.

\section{PENDAHULUAN}

Indonesia merupakan negara kepulauan yang mempunyai kawasan karst yang tersebar di hampir semua pulau-pulau besar dari Sumatra sampai Papua. Namun sampai saat ini keberadaan kawasan karst di Indonesia masih terpinggirkan terutama untuk kawasan konservasi, yang menonjol hanyalah potensi dari sisi ekonomi seperti penambangan batu kapur. Perhatian terhadap potensi kawasan karst dan guanya dari sisi non ekonomi mulai meningkat beberapa tahun terakhir, namun kemauan untuk perlindungan yang menyeluruh belum juga terwujud. Ekosistem karst sampai saat ini belum banyak tersentuh, ekosistem ini menyimpan potensi keanekaragaman hayati yang sangat tinggi baik terestrial maupun akuatik baik di 
Isolasi dan aktivitas antimikroba aktinomycetes dari tanah karst taman wisata Bantimurung asal Maros Sulawesi Selatan

permukaan maupun di dalam gua.

Beberapa penelitian di kawasan karst menunjukkan temuan yang cukup menarik dan mencengangkan dengan banyak ditemukannya jenis baru maupun catatan baru. Sampai saat ini gua-gua di Indonesia menduduki kekayaan keanekaragaman hayati yang tinggi di daerah tropis. ${ }^{1-2}$

Aktinomisetes khususnya Streptomyces dikarakterisasi dengan pertumbuhan koloni yang spesifik. Koloni aktinomisetes bukan akumulasi dari kumpulan sel-sel tunggal dan seragam seperti halnya bakteri, melainkan bentuk masa filamen bercabang. ${ }^{3}$ Koloni yang tumbuh pada medium padat tersusun secara vegetatif dan dengan miselia berantena atau bersungut. Pada koloni yang belum tumbuh miselianya, permukaan koloni terlihat mengkilap. Pada genus Streptomyces, miselium tumbuh secara luas menempel pada medium yang dibentuk oleh Nocardia cenderung mudah terpisah setiap hifanya dan cenderung mudah pecah seperti tepung. Apabila miselium berkembang, permukaannya cenderung seperti tepung dan halus. Struktur, bentuk, ukuran dan warna dari koloni sangat bervariasi dan dapat berubah sesuai dengan kondisi kulturnya. Kebanyakan Streptomyces mengeluarkan bau yang khas seperti tanah. Asam asetat, acetaldehida, etanol, isobutanol, dan isobutil asetat sekarang ini sudah diidentifikasi sebagai aroma senyawa utama yang dihasilkan oleh Streptomyces. Bahkan hidrogen sulfida dipercaya berperan dalam pembentukan aroma tanah yang dikeluarkannya. ${ }^{4}$

Kawasan karst di Sulawesi, salah satunya karst Bantimurung merupakan karst yang membentuk tipe kars tersendiri, yaitu bukit-bukit berlereng terjal. Sebagian besar genesanya dipengaruhi oleh struktur geologi, sebelum diperlebar dan diperluas oleh proses pelarutan atau karsifikasi membentuk bangun menara yang sangat khas (karst tower). Di antara bukit-bukit tersebut membentang dataran dengan permukaannya yang rata. Oleh penduduk setempat, dataran karst tersebut didayagunakan menjadi lahan pertanian dan perkebunan. ${ }^{5}$

Karst adalah sebuah bentuk permukaan bumi yang pada umumnya dicirikan dengan adanya depresi tertutup (closed depression), drainase permukaan, dan gua. Daerah ini dibentuk terutama oleh pelarutan batuan, kebanyakan batu gamping. 
Isolasi dan aktivitas antimikroba aktinomycetes dari tanah karst taman wisata Bantimurung asal Maros Sulawesi Selatan

Kawasan karst di Indonesia mencakup luas sekitar 15,4 juta hektar dan tersebar hampir di seluruh Indonesia. Perkiraan umur dimulai sejak 470 juta tahun lalu sampai yang terbaru sekitar 700.000 tahun. Wilayah karst biasanya berbukit-bukit dengan banyak gua. Maka perlu kiranya dilakukan penelitian didaerah kawasan karst untuk menganalisis jenis mikroorganisme didalamnya yang berpotensi sebagai penghasil antibiotik yang nantinya dapat digunakan dalam pengobatan.

Kata antibiotika diberikan pada produk metabolik yang dihasilkan suatu organisme tertentu, yang dalam jumLah amat kecil bersifat merusak atau menghambat mikroorganisme lain. Dengan perkataan lain, antibiotika merupakan zat kimia yang dihasilkan oleh suatu mikroorganisme yang menghambat mikroorganisme lain. ${ }^{6}$

\section{Berdasarkan mekanisme} aksinya, antibiotik dibedakan menjadi lima yaitu antibiotik dengan mekanisme penghambatan sintesis dinding sel, perusakan membran plasma, penghambatan sintesis protein, penghambatan sintesis asam nukleat dan penghambatan sintesis metabolit essensial. $^{7}$
Kegiatan antibiotika untuk pertama kalinya ditemukan oleh sarjana Inggris dr. Alexander Flemming pada tahun 1928 (penisilin). Penemuan ini baru dikembangkan dan dipergunakan dalam terapi di tahun 1941 oleh dr.Florey (Oxford) yang kemudian banyak zat lain dengan khasiat antibiotika diisolir oleh penyelidik-penyelidik di seluruh dunia, akan tetapi berhubung dengan sifat toksisnya hanya beberapa saja yang dapat digunakan sebagai obat. $^{8}$

Maka penelitian ini bertujuan untuk mengetahui mikroba actinomycetes yang berpotensi sebagai penghasil antibiotik dengan melihat daya hambat yang terbentuk terhadap beberapa mikroba uji pada pengujian antagonis.

\section{METODE PENELITIAN}

\section{Alat dan Bahan yang Digunakan}

Cawan petri (Herma ${ }^{\circledR}$, Normax $\AA$ ) steril, spatula, cawan porselin (Herma®), oven (Memmert $\left.\AA^{\circledR}\right)$, timbangan analitik (Acis $\AA$ CAD-360H), beaker glass (Pyrex®) ukuran $50 \mathrm{~mL}$, pengaduk gelas, botol universal, tabung reaksi (Pyrex®), pipet (Pyrex®) steril, autoklaf (One Med®), ose steril, objek glass, bunsen, tissue, mikroskop (Olympus).

Sampel tanah karst dari taman wisata bantimurung, Alkohol 70\%, 
Isolasi dan aktivitas antimikroba aktinomycetes dari tanah karst taman wisata Bantimurung asal Maros Sulawesi Selatan

medium SNA (Starch Nutrien Agar), NA (Nutrien Agar), PDA (Potato Dekstrosa Agar), SA (Starch Agar).

\section{Prosedur Penelitian}

\section{Rancangan dan Lokasi Penelitian}

Jenis penelitian ini adalah eksperimental laboratorium. Penelitian ini dilaksanakan di Laboratorium Mikrobiologi Fakultas Farmasi Universitas Hasanuddin mulai bulan maret 2016 sampai selesai

\section{Pengambilan sampel}

Pengambilan sampel tanah dilakukan di kawasan karst taman wisata bantimurung, Maros Sulawesi Selatan. Sampel diambil pada kedalaman $5-10 \mathrm{~cm}$.

\section{Pengenceran sampel}

Terlebih dahulu sampel tanah dikeringkan dengan cara dipanaskan didalam oven pada suhu $55-60^{\circ} \mathrm{C}$. Ditimbang sebanyak 1 gram sampel lalu ditambahkan ke dalam $9 \mathrm{~mL}$ air steril (suspensi ini merupakan pengenceran $10^{-1}$ ), lalu disaring. Kemudian $1 \mathrm{~mL}$ suspensi dari pengenceran $10^{-1}$ dimasukkan ke dalam $9 \mathrm{~mL}$ air steril untuk memperoleh pengenceran $10^{-2}$. Hal yang sama dilakukan untuk memperoleh pengenceran $10^{-3}, 10^{-4}$, dan $10^{-5}$.

\section{Isolasi actinomycetes}

Sebanyak $1 \mathrm{~mL}$ suspensi dari masing-masing tingkat pengenceran $\left(10^{-1}-10^{5}\right)$ dinokulasikan secara pour plate padamedium Starch Nitrate Agar (SNA) lalu diinkubasi pada suhu kamar selama $7 \times 24$ jam.

\section{Purifikasi isolat actinomycetes}

Isolat

actinomycetes

diinokulasikan pada medium SNA yang baru secara streak plate, kemudian diinkubasi pada suhu kamar selama $7 \times 24$ jam. Hal ini dilakukan secara berulang hingga diperoleh isolat murni. Selanjutnya isolat murni ditumbuhkan pada medium SNA miring.

\section{Uji Antagonis Isolat actinomycetes}

Uji aktivitas antibakteri dari isolat dilakukan dengan metode agar block. Semua isolat actinomycetes ditumbuhkan ke dalam media SNA, kemudian cakram actinomycetes yang berumur 7 hari inkubasi pada media SNA ditempatkan di permukaan media NA yang telah berisi bakteri uji. Selanjutnya inkubasi selama 24 jam pada suhu $37^{\circ} \mathrm{C}$. Masing-masing isolat diamati kemampuannya menghambat bakteri uji yang ditandai dengan terbentuknya zona jernih disekitar cakram uji dan di evaluasi :>20 mm (strong inhibition), 5-10 mm (moderate 
Isolasi dan aktivitas antimikroba aktinomycetes dari tanah karst taman wisata Bantimurung asal Maros Sulawesi Selatan

inhibition) and $<5 \quad \mathrm{~mm}$ (weak inhibition).

\section{HASIL PENELITIAN}

Telah dilakukan isolasi mikroba aktinomycetes dari tanah daerah kawasan karst pada taman wisata Bantimurung Sulawesi Selatan. Diperoleh hasil penemuan aktinomycetes sebanyak 6 isolat.

Dari 6 isolat kemudian diuji aktivitas daya hambat antimikroba pada mikroba uji Pseudomonas aeruginosa, Staphylococcus aureus dan Candida albicans (Gambar 1).

Diperoleh ada 2 isolat yang memberikan daya hambat terbesar yaitu isolat dengan kode K21 dan K32 (Gambar 2). Kedua isolat ini dinyatakan memiliki potensi sebagai antibiotik dengan memberikan penghambatan terbesar terhadap tiap dua mikroba uji yaitu untuk isolat K21 menghambat pada mikroba uji $P$. aeruginosa $(6,25 \mathrm{~mm})$ dan $S$. aureus(7,69 mm), sedangkan $\mathrm{K} 32$ menghambat mkroba uji $P$. aeruginosa $(7,39 \mathrm{~mm})$ dan C. albicans $(9,03 \mathrm{~mm})$ (Tabel 1).

Tabel 1. Hasil uji antagonis isolat aktinomycetes

\begin{tabular}{cccc}
\hline \multirow{2}{*}{ Isolat } & \multicolumn{3}{c}{ Diameter Hambat $(\mathbf{m m})$} \\
\cline { 2 - 4 } & P. aeruginosa & S. aureus & C. albicans \\
\hline K12 & 6,84 & - & - \\
K21 & 6,25 & 7,69 & - \\
K22 & 5,55 & - & - \\
K32 & 7,39 & - & 9,03 \\
K72 & - & - & - \\
K82 & - & - & - \\
\hline
\end{tabular}

\section{PEMBAHASAN}

Hasil penelitian isolasi aktinomycetes dari tanah kawasan karst taman wisata bantimurung diperoleh 6 isolat aktinomycetes tapi hanya ada 2 isolat yaitu K21 dan K32 yang memberikan aktivitas antimikroba terhadap beberapa mikroba uji yaitu $S$. aureus, E. coli dan C. albicans.

Kawasan Karst Maros-Pangkep sudah dikenal oleh dunia internasional sejak sebelum perang dunia II. Kawasan ini antara lain juga dikenal melalui publikasi ahli geografi Danes. 
Isolasi dan aktivitas antimikroba aktinomycetes dari tanah karst taman wisata Bantimurung asal Maros Sulawesi Selatan

Kawasan ini dikatakan memiliki menara yang memiliki keunikan bentukan alam (geomorfologi) yang geomorfologi yang tiada duanya di amat khas dan tidak dijumpai di Indonesia, keindahan panorama tempat lain. Kawasan Karst Maros- alamnya serta potensi biodiversitasnya Pangkep merupakan kawasan karst juga sangat kaya. ${ }^{9}$

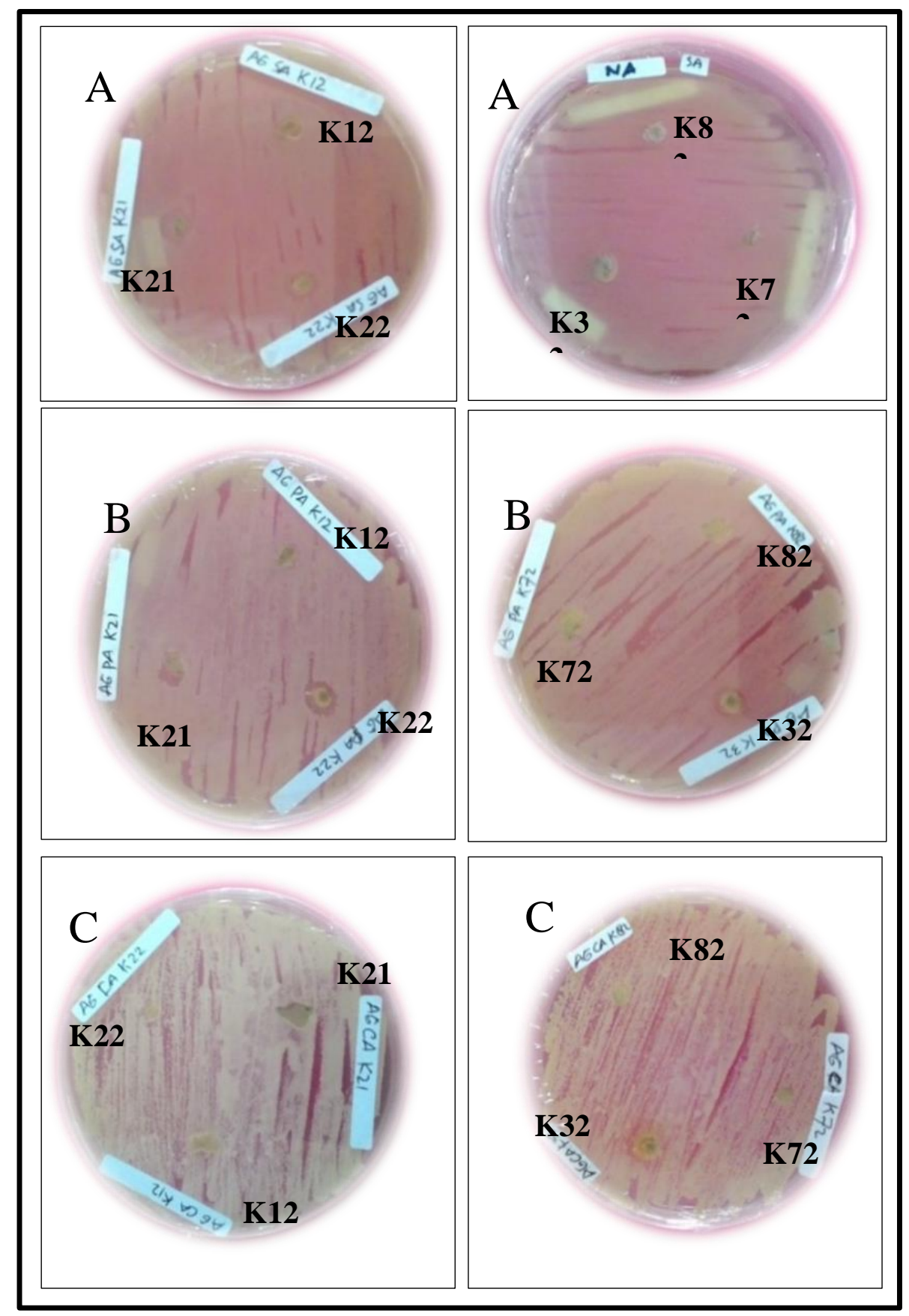

Gambar 1. Hasil Uji Antagoni terhadap beberapa mikroba uji, A :S. aureus, B :E. coli, $\mathbf{C}:$ C. albicans. 
Isolasi dan aktivitas antimikroba aktinomycetes dari tanah karst taman wisata Bantimurung asal Maros Sulawesi Selatan

Tanah yang mempunyai nilai produktivitas yang tinggi,tidak hanya terdiri dari bagian padat, cair dan udara saja, tetapi harus ada jasad hidup yang merupakan organisme hidup. Tanah juga memLiki beberapa jasad hidup, diantaranya Makrofauna : hewan besar penghuni tanah yaitu hewan besar pelubang tanah, cacing tanah, arthropoda dan molusca (gastropoda), Mikro fauna: hewan berukuran mikroskopis yang hidup di dalam tanah yaitu protozoa, nematoda, Makroflora : merupakan tanaman tanaman yang mempunyai akar yang besar yang dapat menembus kedalam tanah, misalnya berbagai macam jenis pepohonan dan Mikro flora: yaitu jenis-jenis flora berukuran mikroskopis yang hidup di dalam tanah misalnya fungi, bakteri, actinomycetes, dan algae. Jenis mikro flora inilah yang paling banyak terdapat dalam tanah, dan diantara mikroorganisme ini, actinomycetes merupakan yang terbanyak.
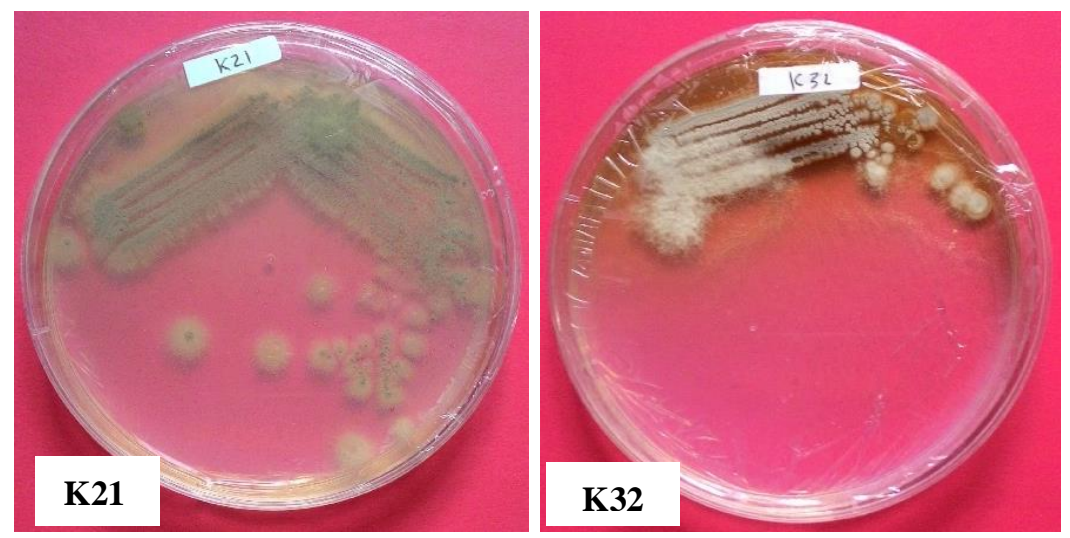

Gambar 2. Isolat aktinomycetes K21 dan K32

Penelitian tentang isolasi aktinomycetes dari tanah di daerah karst telah banyak dilakukan. Telah dilakukan penelitian tentang potensi actinomycetes sebagai sumber senyawa Bioaktif antibiotik dari kawasan karst Bantimurung, Sulawesi Selatan dan menemukan keanekaragaman Actinomycetes yang berhasil diisolasi dan memiliki potensi sebagai penghasil antibiotik sebanyak 14 isolat atau $19,18 \%$ dari total isolat yang berhasil diisolasi. ${ }^{10}$

Actinomycetes, yang strukturnya merupakan bentuk antara dari jamur dan bakteri, menghasilkan zat-zat anti mikroba dan asam amino yang dikeluarkan oleh bakteri fotosintetik dan bahan organik. Actinomycetes dapat hidup bersama 
Isolasi dan aktivitas antimikroba aktinomycetes dari tanah karst taman wisata Bantimurung asal Maros Sulawesi Selatan

dengan bakteri fotosintetik. Streptomyces merupakan salah satu genus dari kelas Actinomycetes yang biasanya terdapat di tanah.

Streptomyces adalah prokariot yang menghasilkan substansi penting untuk kesehatan seperti antibiotik, enzim, dan immunomodulator dan salah satu organisme tanah yang memiliki sifat-sifat umum yang dimiliki oleh bakteri dan jamur tetapi juga memiliki ciri khas yang cukup berbeda yang membatasinya menjadi satu kelompok yang jelas berbeda. Banyak anggota dari Streptomyces menghasilkan antibiotik di mana lebih dari setengahnya merupakan antibiotik yang efektif melawan bakteri, misalnya streptomisin, tetrasiklin dan kloramfenikol, maka dilakukan pencarian mikroorganisme penghasil antibiotik dalam mengobati penyakit infeksi yang sedang berkembang saat ini.

Uji pendahuluan dilakukan dengan beberapa perlakuan. Perlakuan pertama menggunakan medium spesifik, yaitu SNA (Starch Nitrate Agar) kemudian dimasukkan sampel tanah yang telah mengalami pengenceran $10^{-1}$ sampai $10^{-5}$.

SNA merupakan salah satu media yang mengandung sumber karbon dan mineral-mineral yang dibutuhkan untuk pertumbuhan actinomycetes. Sumber karbon dari media SNA berasal dari soluble starch yang mengandung sejumLah karbon yang beragam dari pati dan gliserol. Sumber nitrogen anorganik $\left(\mathrm{NO}_{3}{ }^{-}\right)$ berasal dari $\mathrm{KNO}_{3}$, mineral-mineral yang berasal dari magnesium, natrium, besi, dan kalium yang merupakan komposisi dari media tersebut. ${ }^{11}$ Sedangkan pengenceran bertujuan untuk mengurangi pertumbuhan mikroba, sehingga lebih memudahkan saat proses isolasi dan pengamatan.

Perlakuan kedua yaitu medium SNA ditambahkan nystatin untuk menghambat pertumbuhan fungi dan jamur, kemudian dimasukkan sampel tanah yang dipanaskan pada suhu $55-60^{\circ} \mathrm{C}$. Tujuan pemanasan untuk mengurangi pertumbuhan bakteri lain tetapi tidak membunuh mikroba aktinomycetes karena aktinomycetes masih dapat bertahan pada suhu tersebut.

Isolasi mikroba dari alam merupakan tahap awal dalam penapisan metabolit mikroba seperti antibiotik. Biasanya tidak diketahui jenis dan jumLah mikroba dalam sampel tersebut. Pada prinsipnya tujuan isolasi mikroba yaitu untuk 
Isolasi dan aktivitas antimikroba aktinomycetes dari tanah karst taman wisata Bantimurung asal Maros Sulawesi Selatan

mendapatkan mikroba yang

dikehendaki sebanyak-banyaknya. ${ }^{12}$

Untuk maksud tersebut dapat digunakan teknik medium diperkaya dan sistem pengenceran. Misalnya sampel tanah atau air diencerkan sedemikian rupa, sehingga diharapkan pertumbuhan koloni tidak lebih 200 koloni per cawan petri. Suspensi tersebut dengan metode taburan spread plate diinokulasikan pada cawan petri yang mengandung medium diperkaya. Setelah diinkubasi, akan terlihat koloni-koloni pada cawan tersebut dan siap untuk diisolasi. $^{13}$

Setelah dilakukan isolasi mikroba aktinomycetes kemudian dilakukan purifikasi isolat. Hal ini dilakukan untuk memurnikan isolat terpilih dari adanya kontaminasi mikroba lain, sehingga isolat yang akan diujikan bebas dari aktivitas mikroba lainnya. Setelah purifikasi dilakukan tahap akhir yaitu uji antagonis terhadap beberapa mikroba uji, uji ini untuk melihat adanya daya hambat isolat terpilih sehingga dapat diketahui isolat yang bersifat sebagai antimikroba.

\section{KESIMPULAN}

Hasil isolasi aktinomycetes dari tanah kawasan karst taman wisata bantimurung diperoleh 6 isolat aktinomycetes tapi hanya ada 2 isolat yaitu K21 dan K32 yang memberikan aktivitas antimikroba terhadap beberapa mikroba uji.

\section{DAFTAR PUSTAKA}

1. Benzon. Microbiological applications Laboratory Manual in General Microbiology : The Mc Graw Hill Company. Eight Edition. New York, 2001.

2. Deharveng $L$. The cave fauna of Southeast Asia:origin : evolution and ecology in. Wilkens, H., Culver, D.C, and Humpreys, W.F. (eds), Ecosystem ofthe world, Vol. 30: Subterranean Ecosystem Elsevier. Amsterdam , 2000.

3. Locci R. Morphology ; 1983. di dalam: Goodfellow M., Mordarski M, Williams ST. The biology of the actinomycetes : Academic Press. London ; 1984.

4. Goodfellow M. Ecology of actinomycetes. Ann Rev Microbiol $1983 ; 37: 189-216$.

5. Setiadi. Dasar-dasar Ekologi. Bogor ; 1889.

6. Pelczar MJ. Dasar-dasar Mikrobiologi, Penerjemah R.S.Hadiotomo dkk : Ul-Press. Jakarta , 2005.

7. Pratiwi ST. Mikrobiologi Farmasi. Erlangga: Jakarta, 2008.

8. Djide MN. Mikrobiologi Farmasi. Laboratorium Mikrobiologi Farmasi dan Bioteknologi Farmasi. Makassar: Jurusan Farmasi 
Isolasi dan aktivitas antimikroba aktinomycetes dari tanah karst taman wisata Bantimurung asal Maros Sulawesi Selatan

Fakultas MIPA Universitas Hasanuddin, 2003.

9. Ko RKT. Kawasan Karst MarosPangkep, Nilai Lebihnya dalam Bidang Non Pertambangan. Prosiding Simposium Karst MarosPangkep : Menuju Perlindungan dan Pemanfaatan Kawasan Karst Maros-Pangkep sebagai World Heritage di Era Otonomi Daerah : Badan Pengendalian Dampak Lingkungan Regional III. Makassar, 2001.

10. Kumalasari AM. Potensi Actinomycetes Sebagai Sumber Senyawa Bioaktif Antibiotik Dari
Kawasan Karst Bantimurung : PELITA. Sulawesi Selatan. Volume VII: (1), 2012.

11. Mulyadi. Aktivitas cairan kultur 12 isolat actinomycetes terhadap bakteri resisten. KESMAS 2013;. 7(2): pp. 55-112.

12. Morello JA. Laboratory manual and workbook in microbiology applications to patient care : The McGraw-Hill Companies. New York ; 2002.

13. Hogg S.. Essential microbiology : John Wiley and Son Inc. England; 2005. 